\title{
Pervious concrete, plastic concrete and controlled low strength material- a special applications concrete
}

\author{
Ojha P N, Suresh Kumar, Brijesh Singh*, Mohapatra B N
}

\begin{abstract}
National Council for Cement and Building Materials, India.
* Corresponding Author: brijeshsehwagiitr96@gmail.com
\end{abstract}

Received: 31-08-2020

Accepted: 25-11-2020

\begin{abstract}
The paper presents the study carried out for three special concretes like Pervious Concrete, Plastic Concrete and Controlled Low Strength Materials (CLSM) using locally available materials. Pervious concrete is a concrete with high porosity. It is used in a wide range of applications including pervious pavements and helps in improving pavement skid resistance and reducing hydroplaning. This concrete was designed to meet the requirement of 28-day compressive strength of $10 \mathrm{MPa}$ and water permeability of $0.50 \mathrm{~cm} / \mathrm{sec}$. Plastic concrete has low compressive strength but higher ductility and lower permeability. It is used for creating an impermeable barrier (cut-off wall) for containment of contaminated sites or seepage control in highly permeable dam foundations. This concrete was designed to meet the requirement of 28-day unconfined compressive strength of 1.5 to $2.5 \mathrm{MPa}$ and confined compressive strength of 2.5 to $3.5 \mathrm{Mpa}$ at confining pressure of $4 \mathrm{Kg} / \mathrm{cm}^{2}$. Controlled Low Strength Material (CLSM) or flowable fill mixtures are typically specified and used in place of compacted fill especially for backfill, utility bedding, void fill and bridge approaches. CLSM is a self-compacting, flowable, low strength cementitious material which suits the requirement of different applications such as excavatable backfill and structural backfill. The properties of CLSM that were investigated included bleeding, density of hardened CLSM, permeability and unconfined compressive strength at 7 days and 28 days age.
\end{abstract}

Key words: Plastic Concrete, Pervious Concrete, Controlled Low Strength Material.

\section{Introduction}

Pervious concrete is an open graded, zero slump material consisting of Portland cement, coarse aggregate, little or no fine aggregate, admixture and water (ACI, 2006). It is also called porous concrete, permeable concrete and no fines concrete. It is a concrete with high porosity resulting from a network of inter-connected pores in the hardened state of concrete. Pervious concrete contains pores, ranging in size from 2 to $8 \mathrm{~mm}$ that allow water to pass through quickly. The void content in pervious concrete can range from $35 \%$ to $18 \%$ with typical compressive strengths of 2.8 to $28 \mathrm{MPa}$ and water permeability generally falls in the range of 81 to 730 $\mathrm{L} / \mathrm{min} / \mathrm{m}^{2}$ (0.135 to $1.22 \mathrm{~cm} / \mathrm{s}$ ) (ACI, 2006). Pervious concrete has its various environmental benefits such as controlling storm runoff, restoring groundwater supplies, and reducing water and soil pollution (Youngs, 2005; Kajio et al., 1998). Pervious concrete made with single-sized coarse aggregates generally have high permeability but not adequate strength. Addition of a small amount of fine sand to the mixes significantly improves the concrete strength and freezethawing resistance while maintaining adequate water permeability (Wang et al., 2006). The use of pervious concrete is the solution to overcoming a lot of environmental problems by reducing tire-pavement interaction noise, moderating storm-water runoff, and limiting the pollutants entering the groundwater, mean that an aggregate storage bed will reduce the stormwater runoff volume, rate, and pollutants appropriately. Pervious concrete also affects durability by reducing the surface temperature of the paved area. Hence, the main function of pervious concrete lies in its ability to transport a large volume of water through its pores to the underlying strata, and it serves as a pavement for vehicles and pedestrians. 
Plastic concrete, which is sometimes referred to as low strength concrete or artificial soil, consists of aggregate, cement, water, and bentonite clay mixed at a high water-cement ratio to produce a ductile material (Naderi, 2005). Plastic concrete has lower compressive strength, higher formability and lower permeability. The addition of Bentonite reduces concrete hardness and elasticity coefficient. Due to this reason, plastic concrete is used in the construction of cut off walls to reduce seepage through the foundation of earth dams. Plastic concrete is also used for control of infiltration of harmful sewage and the penetration of sea water, and more recently for filling the surrounding of water ducts in power plants (Naderi, 2005).

CLSM is a self-compacting flowable, low strength cementitious material consisting of lower cement content, higher fly ash and fine aggregate content, no coarse aggregate, mixed at high water-cement ratio. CLSM is used primarily as backfill, void fill and utility bedding as an alternative to compacted fill. Several terms are currently used to describe this material, including flowable fill, unshrinkable fill, controlled density fill, flowable mortar, plastic soilcement, soil-cement slurry, K-Krete and other various names (Katz and Kovler, 2004). Controlled low strength materials are as materials that result in a compressive strength of 8.3 MPa or less (ACI, 1990). However, most current CLSM applications require unconfined compressive strength of $2.1 \mathrm{MPa}$ or less. This low strength requirement is necessary to allow for further excavation of CLSM in future. Because CLSM flows and needs no compaction, it is ideal for use in tight or restricted access where placing and compacting soil or granular fill is difficult or even impossible. The cost of CLSM is influenced by the cost and local availability of materials, the mixing and transportation method, and the methods of placement.

Conventional concrete is a material composed of cement, coarse aggregate, fine aggregate, water and admixture, primarily designed taking two properties i.e. compressive strength and workability into consideration. However, for special category modified concrete, apart from these two parameters, other properties like high permeability in case of pervious concrete, low permeability, high strain and low modulus of elasticity in case of plastic concrete and controlled strength and low permeability in case of controlled low strength material are taken into consideration before finalizing the mix proportions.

Special concrete is a type of concrete which meets the special performance requirements. The aim of this study is to evaluate the performance of three different types of special applications concrete such as Pervious Concrete, Plastic Concrete and Controlled Low Strength Materials (CLSM) using locally available materials in civil engineering construction.

\section{Special applications concrete}

\subsection{Pervious Concrete}

OPC 43 Grade conforming to IS: 8112-2013, fine aggregate (Zone-II) and coarse aggregate (12 mm downsize) conforming to IS: 383 were used in the study carried out for pervious concrete. The mix formulation used in the investigation is shown in Table 1. The mix proportioning is done using absolute volume method by varying percentage of sand by volume in total aggregate at $0 \%$ and $5 \%$. The water cement ratio is an important consideration for maintaining strength and the void structure of the concrete. Experience has shown a range of 0.35 to 0.45 will provide the best aggregate coating and paste stability (ACI, 2002). The water cement ratio selected in the present study is 0.35 and 0.40 . The proportions for the pervious concrete were designed for cement contents ranging from 200 to $250 \mathrm{~kg} / \mathrm{m}^{3}$. The pervious concrete was designed for 28-day characteristic strength of $10 \mathrm{MPa}$ and minimum water permeability of $0.50 \mathrm{~cm} / \mathrm{sec}$ with no slump workability. Due to the permeability requirement, pervious concrete is typically designed with high void content (15-25\%). Single sized aggregate is commonly used to achieve such void content (Tennis et al., 2004). The mix-design trials were carried out by varying the theoretical 
porosity between 20 to $28 \%$. The theoretical porosity was calculated as per the following procedure:

Total voids in coarse aggregate system =

$\underline{\text { (Absolute density of coarse aggregate - Dry rodded bulk density of coarse aggregate) }} \times 100$

Absolute density of coarse aggregate

Theoretical porosity adopted for mix design $=$ Total voids in coarse aggregate system absolute volume of mortar constituents

Where, absolute volume of mortar constituents

absolute volume of cement, water and fine
aggregate if any

Sample illustration for trial given in Sl No. 1 of Table1:

Dry rodded bulk density of coarse aggregate

Absolute density of coarse aggregate

Total voids in coarse aggregate system

Absolute volume of cement

Absolute volume of water

Absolute volume of mortar constituents

Theoretical porosity

Theoretical porosity adopted for mix design

$$
\begin{aligned}
& =1502 \mathrm{~kg} / \mathrm{m}^{3} \\
& =2660 \mathrm{~kg} / \mathrm{m}^{3} \\
& =\frac{2660-1502}{2660} \times 100=43 \% \\
& =\frac{200}{3.15} \times \frac{1}{1000}=0.0635 \\
& =\frac{70}{1} \times \frac{1}{1000}=0.070
\end{aligned}
$$

$=$ Absolute volume of cement + absolute volume of water

$=0.0635+0.07$

$=0.1335$

$=$ Total voids in coarse aggregate system absolute volume of mortar constituents.

$=0.43-0.1335$

$=0.2965$ i.e. $\approx 29 \%$

$=28 \%$

Similarly, the theoretical porosity for trials given in Sl No. 2 to 8 can be found out.

However, the actual porosity in hardened concrete might be different from the theoretical porosity adopted at the time of mixing. This is due to the hydration reaction of cement which results in formation of $\mathrm{C}-\mathrm{S}-\mathrm{H}$ gel which has specific gravity in the range of 2.1 to 2.2 which is lesser as compared to the specific gravity of cement. Secondly, some water also gets evaporated during the hardening process of concrete. This also results in different porosity in the hardened concrete.

Actual porosity in pervious concrete in the hardened state can be calculated as: 
Actual porosity

(Theoretic al porosity $\mathrm{x}$ weight of all concrete constituents per cum)

Actual porosity for Sl. No. 1 of Table-1 $=\frac{(28 \times 1830)}{1955}=26 \%$

Similarly the actual porosity for trials given in Sl No. 2 to 8 can be found out.

The compressive strength test of pervious concrete was carried out on cube specimens of size $150 \mathrm{~mm} \times 150 \mathrm{mmx} 150 \mathrm{~mm}$ as per IS: $516-1959$. The water permeability test was carried out on cylindrical specimens of size $100 \mathrm{~mm}$ diameter and $200 \mathrm{~mm}$ height as per ISO/DIS-17785-1. Fig. 1 shows the pervious concrete specimens and fig. 2 shows the permeability test set up.

Table 1. Trials conducted for Pervious Concrete

\begin{tabular}{|c|c|c|c|c|c|}
\hline Sl. No. & $\begin{array}{l}\text { Water Content } \\
\left(\mathrm{kg} / \mathrm{m}^{3}\right)\end{array}$ & $\begin{array}{l}\text { Cement Content } \\
\left(\mathrm{kg} / \mathrm{m}^{3}\right)\end{array}$ & $\begin{array}{l}\text { Fine aggregate } \\
\text { content }\left(\mathrm{kg} / \mathrm{m}^{3}\right)\end{array}$ & $\begin{array}{l}\text { Coarse aggregate } \\
\text { content }\left(\mathrm{kg} / \mathrm{m}^{3}\right)\end{array}$ & $\begin{array}{l}\text { Theoretical } \\
\text { Porosity }(\%)\end{array}$ \\
\hline \hline Mix 1 & 70 & 200 & Nil & 1560 & 28.0 \\
\hline Mix 2 & 80 & 200 & Nil & 1560 & 27.0 \\
\hline Mix 3 & 87 & 250 & Nil & 1552 & 25.0 \\
\hline Mix 4 & 100 & 250 & Nil & 1544 & 24.0 \\
\hline Mix 5 & 70 & 200 & 83 & 1583 & 24.0 \\
\hline Mix 6 & 80 & 200 & 83 & 1583 & 23.0 \\
\hline Mix 7 & 87 & 250 & 83 & 1576 & 21.0 \\
\hline Mix 8 & 100 & 250 & 82 & 1568 & 20.0 \\
\hline
\end{tabular}

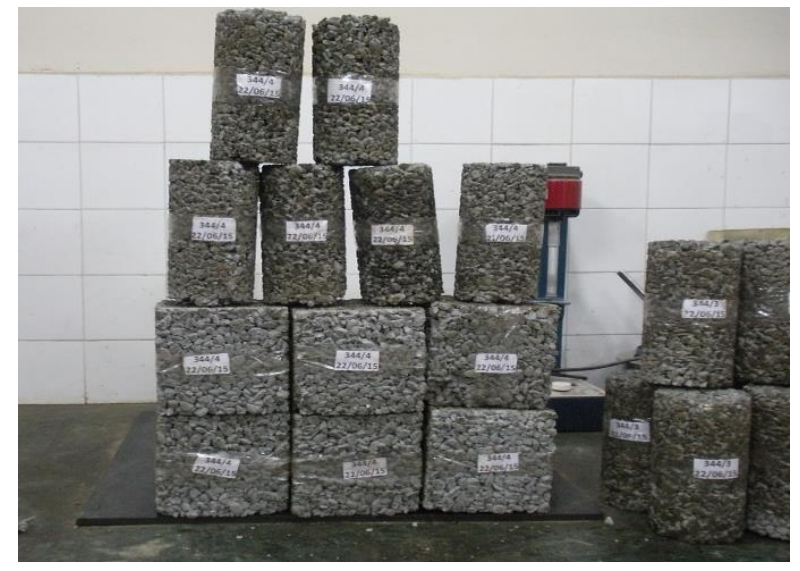

Fig. 1. Pervious concrete cube specimens for compressive strength $\&$ cylindrical specimens for permeability test

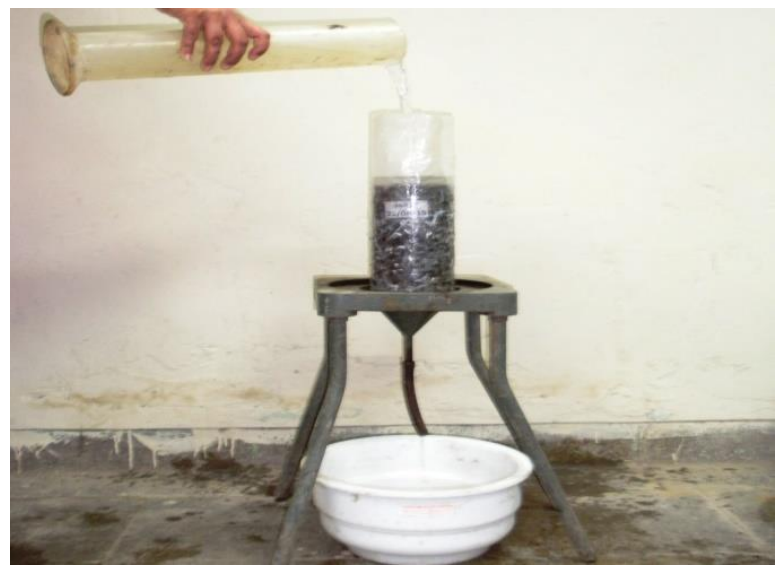

Fig. 2. Permeability Test of Pervious Concrete

\subsection{Plastic Concrete}

PPC conforming to IS: 1489 (Part 1), fine aggregate (Zone III) and coarse aggregate $(20 \mathrm{~mm}$ downsize) conforming to IS: 383-1970 and Bentonite were used in the study of plastic concrete. The mix formulation used in the investigation is shown in Table 2. The proportions for the plastic concrete were designed for cement contents ranging from 150 to $200 \mathrm{~kg} / \mathrm{m}^{3}$ and bentonite contents between 20 to $40 \mathrm{~kg} / \mathrm{m}^{3}$. The plastic concrete was designed for 28-day unconfined compressive strength of 2.0 MPa and confined compressive strength of 3.0 MPa with 
the slump requirement of 180-195 mm. For the purpose of preparation of plastic concrete, first of all Bentonite is mixed thoroughly with water and is mixed for 24 hours. Then slurry is poured in the mixer and mixed for one minute, then cement is added and after another minute, the aggregates are added to the mixture and mixed for another 7 to 10 minutes. Slump, air content, density and setting time tests were performed on fresh concrete. To determine the unconfined compressive strength, strain at failure and young modulus of concrete, cylindrical specimens of size $150 \mathrm{~mm}$ diameter and $300 \mathrm{~mm}$ height were cast. Cylindrical specimens of size $100 \mathrm{~mm}$ diameter and $200 \mathrm{~mm}$ height were cast for confined test. To determine water permeability, cylindrical specimens of size $150 \mathrm{~mm}$ diameter and $150 \mathrm{~mm}$ height were cast. Concrete slab of size $300 \mathrm{~mm} \times 300 \mathrm{mmx} 100 \mathrm{~mm}$ were cast to determine the abrasion resistance of plastic concrete. The specimens were de-moulded after 24 hours of casting and stored in water tank at a temperature of $27^{\circ} \mathrm{C} \pm 2 \stackrel{\circ}{\circ} \mathrm{C}$. Fig. 3 \& 4 show the unconfined and confined test set respectively.

Table 2. Trials conducted for Plastic Concrete

\begin{tabular}{|c|c|c|c|c|c|c|c|}
\hline \multirow{2}{*}{\multicolumn{2}{|c|}{ Mix ID }} & \multirow{2}{*}{$\begin{array}{l}\text { Cement } \\
\text { content } \\
\left(\mathrm{kg} / \mathrm{m}^{3}\right)\end{array}$} & \multirow{2}{*}{$\begin{array}{l}\text { Water } \\
\text { content } \\
\left(\mathrm{kg} / \mathrm{m}^{3}\right)\end{array}$} & \multirow{2}{*}{$\begin{array}{l}\text { Bentonite } \\
\text { content } \\
\left(\mathrm{kg} / \mathrm{m}^{3}\right)\end{array}$} & \multirow{2}{*}{$\begin{array}{l}\text { Fine } \\
\text { aggregate } \\
\text { content } \\
\left(\mathrm{kg} / \mathrm{m}^{3}\right)\end{array}$} & \multicolumn{2}{|c|}{$\begin{array}{l}\text { Coarse aggregate content } \\
\left(\mathrm{kg} / \mathrm{m}^{3}\right)\end{array}$} \\
\hline & & & & & & $\begin{array}{l}(10-20 \mathrm{~mm} \\
\text { Fraction) }\end{array}$ & $\begin{array}{l}(<10 \mathrm{~mm} \\
\text { Fraction })\end{array}$ \\
\hline \multirow[t]{3}{*}{ Set A } & 1 & 150 & 290 & 20 & 877 & 528 & 352 \\
\hline & 2 & 150 & 290 & 25 & 875 & 527 & 351 \\
\hline & 3 & 150 & 290 & 30 & 872 & 525 & 350 \\
\hline \multirow[t]{2}{*}{ Set B } & 4 & 165 & 290 & 20 & 870 & 524 & 349 \\
\hline & 5 & 165 & 290 & 40 & 859 & 518 & 345 \\
\hline \multirow[t]{3}{*}{ Set C } & 6 & 200 & 290 & 20 & 854 & 514 & 343 \\
\hline & 7 & 200 & 290 & 25 & 851 & 513 & 342 \\
\hline & 8 & 200 & 290 & 40 & 843 & 508 & 338 \\
\hline
\end{tabular}

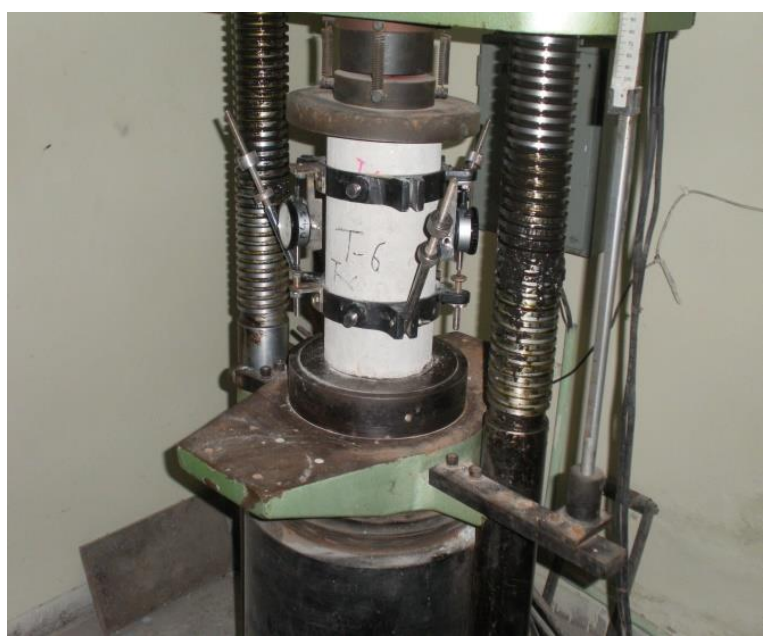

Fig. 3. Unconfined Test on Plastic Concrete

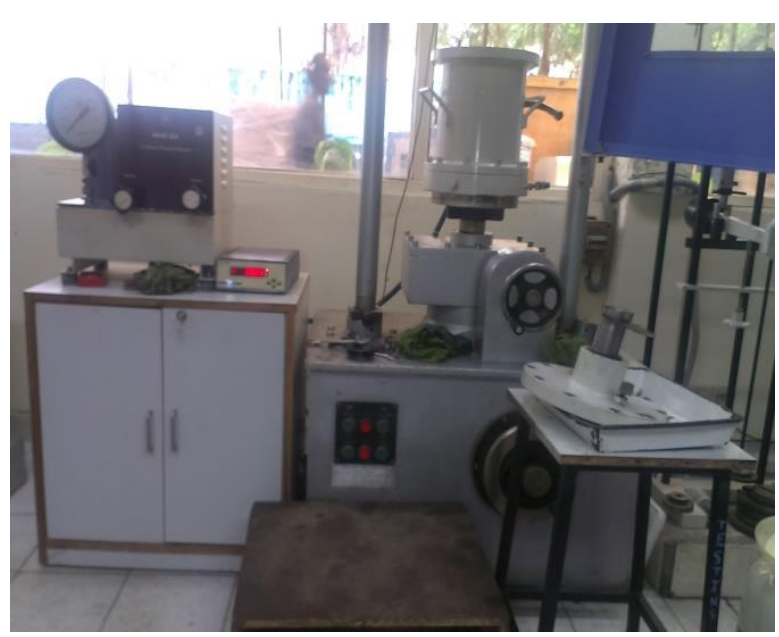

Fig. 4. Confined Test on Plastic Concrete at Confining Pressure of $4 \mathrm{~kg} / \mathrm{cm}^{2}$

\subsection{Controlled Low Strength Material}

OPC 43 Grade conforming to IS: 8112-2013, fine aggregate (Zone I) conforming to per IS: 383 and siliceous fly ash conforming to IS: 3812 (Part 2)-2003 were used in the study of CLSM. However, it is not necessary to use the standardized materials as set by many available standard 
requirements (ACI, 1994). The mix formulation used in the investigation is shown in Table 3. The proportions for the CLSM mixtures were designed for target cement contents ranging from 30 to $70 \mathrm{~kg} / \mathrm{m}^{3}$ and fly ash contents between 460 and $1200 \mathrm{~kg} / \mathrm{m}^{3}$.The CLSM was designed for 28-day strength of $0.52 \mathrm{MPa}$ with the slump requirement of $175-200 \mathrm{~mm}$. The Target mean strength is calculated by using the equation i.e. $\mathrm{f}_{\mathrm{ck}}+1.65^{*} \mathrm{~S}$, where $\mathrm{S}$ is assumed standard deviation as $20 \%$ of required characteristics strength at 28-day.The mixing was in a pan mixer for 2 to 3 minutes and workability of CLSM mix was checked using slump cone method as per IS 1199:1959. The cube specimens of size $100 \mathrm{~mm} \times 100 \mathrm{~mm} \times 100 \mathrm{~mm}$ and cylindrical specimens of size $150 \mathrm{~mm}$ diameter and $150 \mathrm{~mm}$ height were cast without any vibration. The specimens were stored in a place free from vibration, in moist air of $>90 \%$ relative humidity and at a temperature of $27^{\circ} \mathrm{C} \pm 2^{\circ} \mathrm{C}$ until the fourth day after preparation. Humidity chamber were used to maintain these condition. On the fourth day, specimens were placed in a water curing tank. Fig. 5 shows the water permeability test set up and fig. 6 shows the compressive strength test set up of CLSM.

Table 3. Trials conducted for CLSM

\begin{tabular}{|l|c|c|c|c|}
\hline Sl. No. & $\begin{array}{l}\text { Water Content } \\
\left(\mathrm{Kg} / \mathrm{m}^{3}\right)\end{array}$ & $\begin{array}{l}\text { Cement Content } \\
\left(\mathrm{Kg} / \mathrm{m}^{3}\right)\end{array}$ & $\begin{array}{l}\text { Fly ash Content } \\
\left(\mathrm{Kg} / \mathrm{m}^{3}\right)\end{array}$ & $\begin{array}{l}\text { Fine aggregate } \\
\text { Content }\left(\mathrm{Kg} / \mathrm{m}^{3}\right)\end{array}$ \\
\hline \hline Mix-1 & 250 & 30 & 460 & 1364 \\
\hline Mix-2 & 250 & 50 & 460 & 1347 \\
\hline Mix-3 & 250 & 70 & 460 & 1330 \\
\hline Mix-4 & 290 & 30 & 800 & 839 \\
\hline Mix-5 & 304 & 50 & 800 & 786 \\
\hline Mix-6 & 355 & 50 & 1000 & 405 \\
\hline Mix-7 & 375 & 30 & 1200 & 122 \\
\hline
\end{tabular}

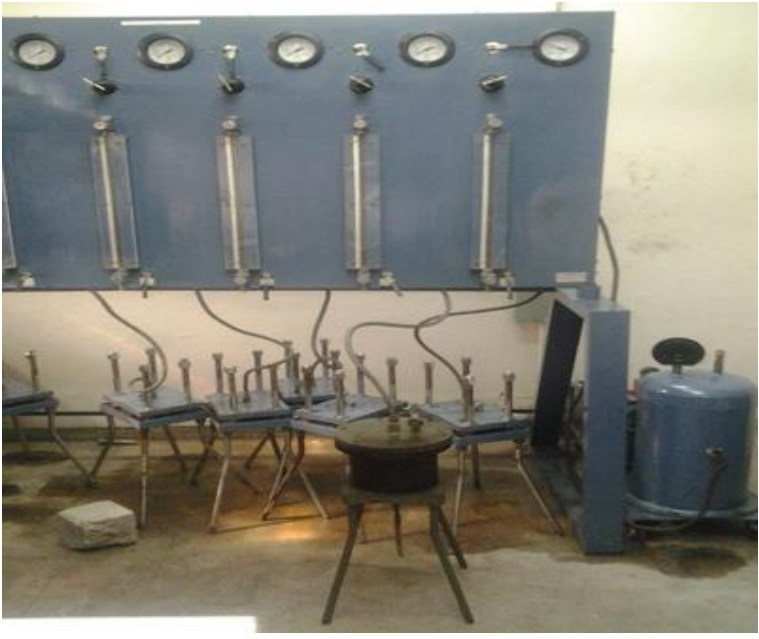

Fig. 5. Permeability Test of CLSM

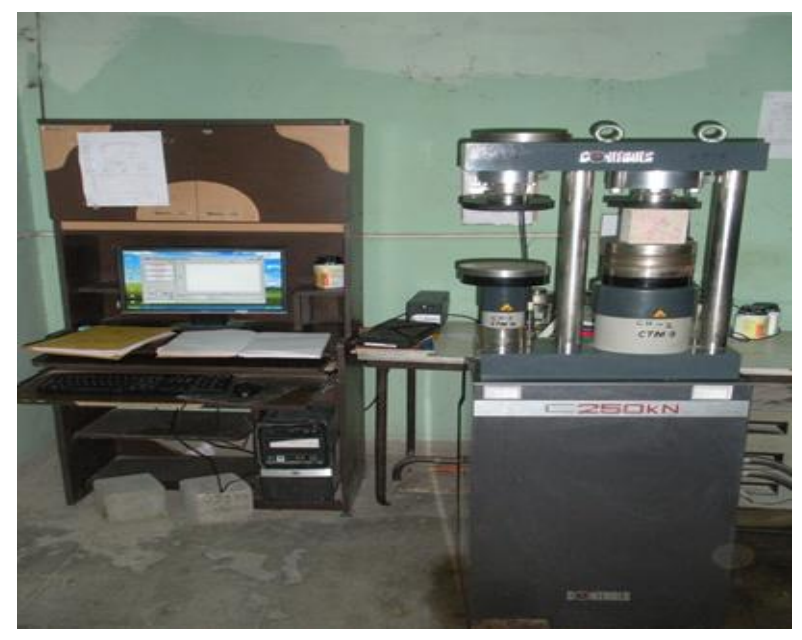

Fig. 6. Compressive Strength Test

\section{Test result and discussions}

\subsection{Pervious Concrete}

The test results of properties studied such as compressive strength, water permeability and density are discussed below and given in Table 4: 
Table 4. Test Results

\begin{tabular}{|l|c|c|c|c|c|c|}
\hline $\begin{array}{l}\text { Sl. } \\
\text { No. }\end{array}$ & $\begin{array}{l}\text { Dry } \\
\text { Density } \\
\left(\mathrm{kg} / \mathrm{m}^{3}\right)\end{array}$ & $\begin{array}{l}\text { Actual } \\
\text { Porosity } \\
(\%)\end{array}$ & $\begin{array}{l}\text { 7-day comp. } \\
\text { strength of } \\
\text { cubes }\left(\mathrm{N} / \mathrm{mm}^{2}\right)\end{array}$ & $\begin{array}{l}\text { 28-day comp. } \\
\text { strength of } \\
\text { cubes }\left(\mathrm{N} / \mathrm{mm}^{2}\right)\end{array}$ & $\begin{array}{l}\text { 7-day } \\
\begin{array}{l}\text { Permeability } \\
(\mathrm{cm} / \mathrm{sec})\end{array}\end{array}$ & $\begin{array}{l}\text { 28-day } \\
\text { Permeability } \\
(\mathrm{cm} / \mathrm{sec})\end{array}$ \\
\hline 1 & 1955 & 26.0 & 9.05 & 11.72 & 1.40 & 1.25 \\
\hline 2 & 1976 & 25.0 & 8.27 & 11.10 & 0.76 & 0.63 \\
\hline 3 & 2004 & 23.5 & 10.39 & 12.51 & 0.55 & 0.55 \\
\hline 4 & 1957 & 22.0 & 7.38 & 10.07 & 0.66 & 0.38 \\
\hline 5 & 1972 & 23.5 & 11.30 & 13.51 & 1.11 & 1.02 \\
\hline 6 & 1988 & 22.5 & 8.30 & 13.66 & 0.71 & 0.58 \\
\hline 7 & 2013 & 20.8 & 12.79 & 15.82 & 0.40 & 0.37 \\
\hline 8 & 2076 & 19.3 & 9.20 & 11.44 & 0.31 & 0.23 \\
\hline
\end{tabular}

- Water permeability increased with increase in theoretical porosity for no fines concrete as well as for concrete with 5\% fines as shown in Fig 7 \& 8 .

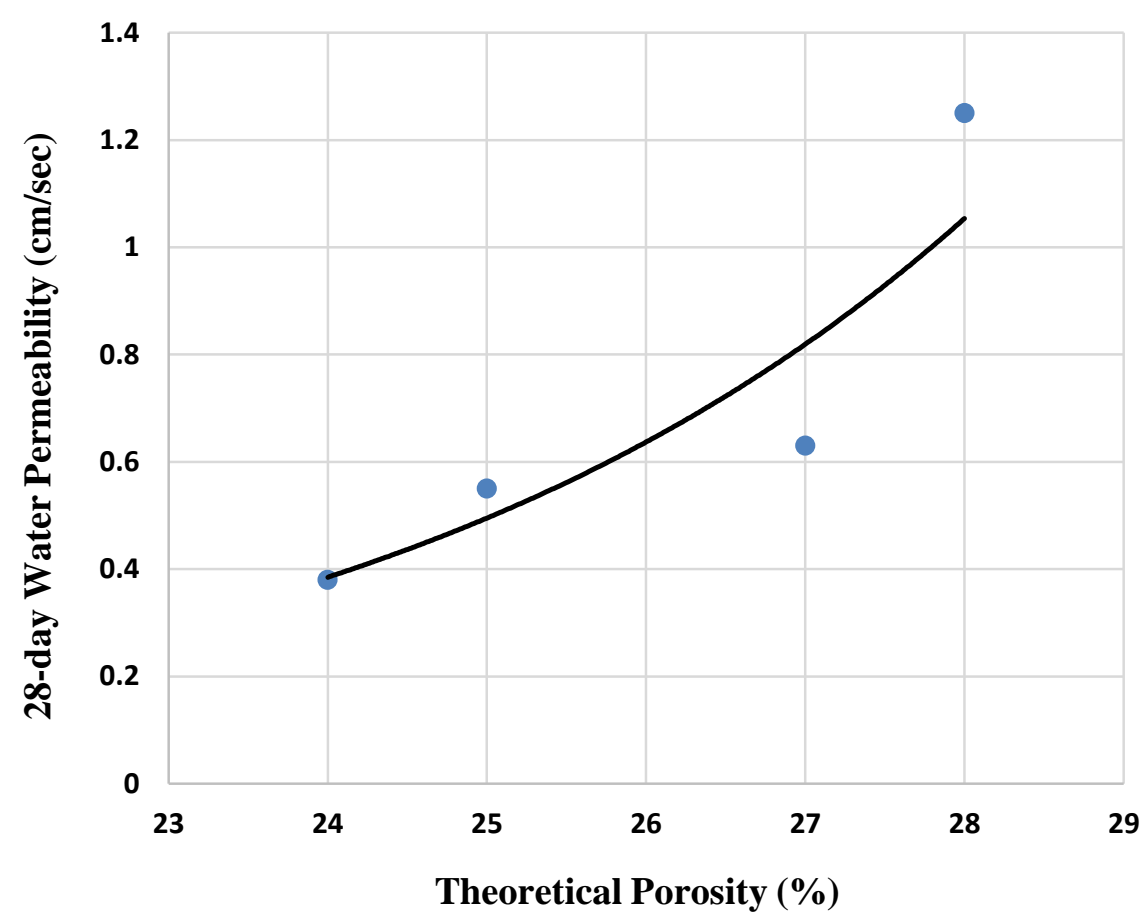

Fig. 7. Theoretical Porosity vs Water Permeability for no fines pervious concrete 


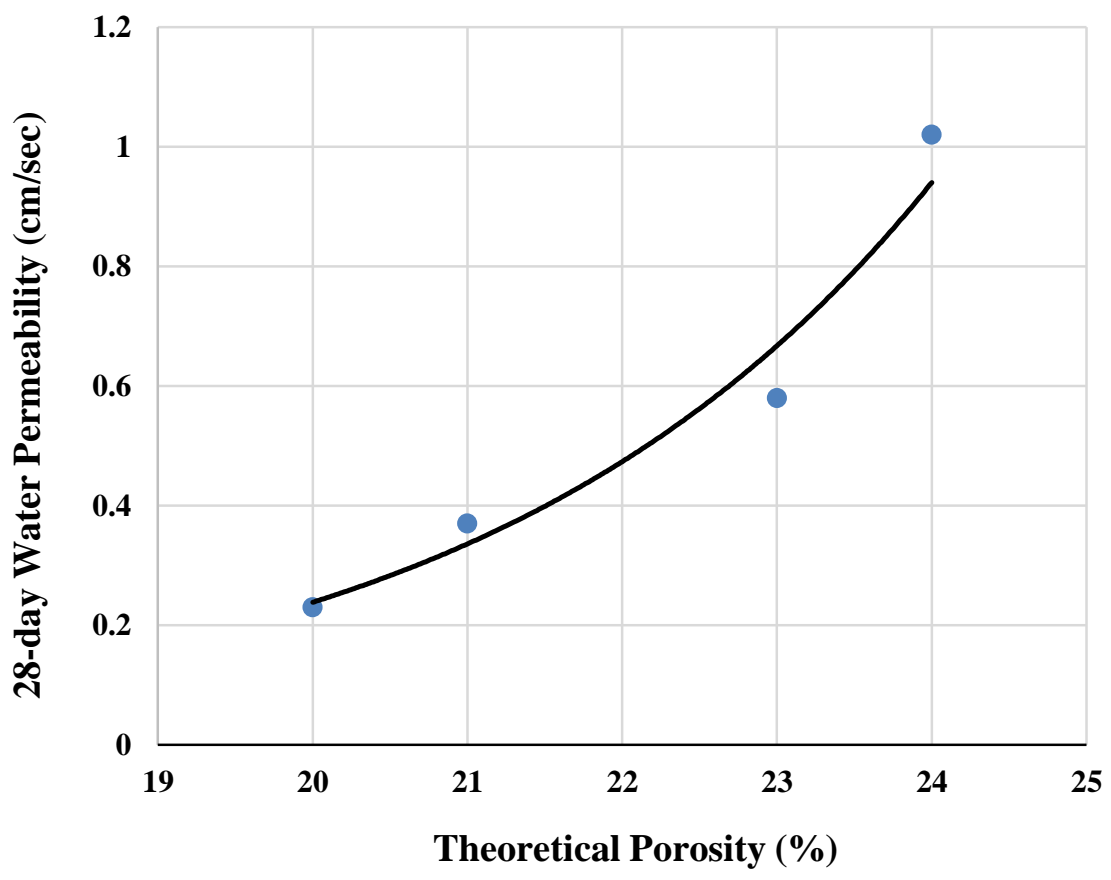

Fig. 8. Theoretical Porosity vs Water Permeability for pervious concrete with $\mathbf{5 \%}$ fines

- Dry density of pervious concrete decreased with increase in theoretical porosity for no fines concrete as well as for concrete with 5\% fines as shown in Fig $9 \& 10$.

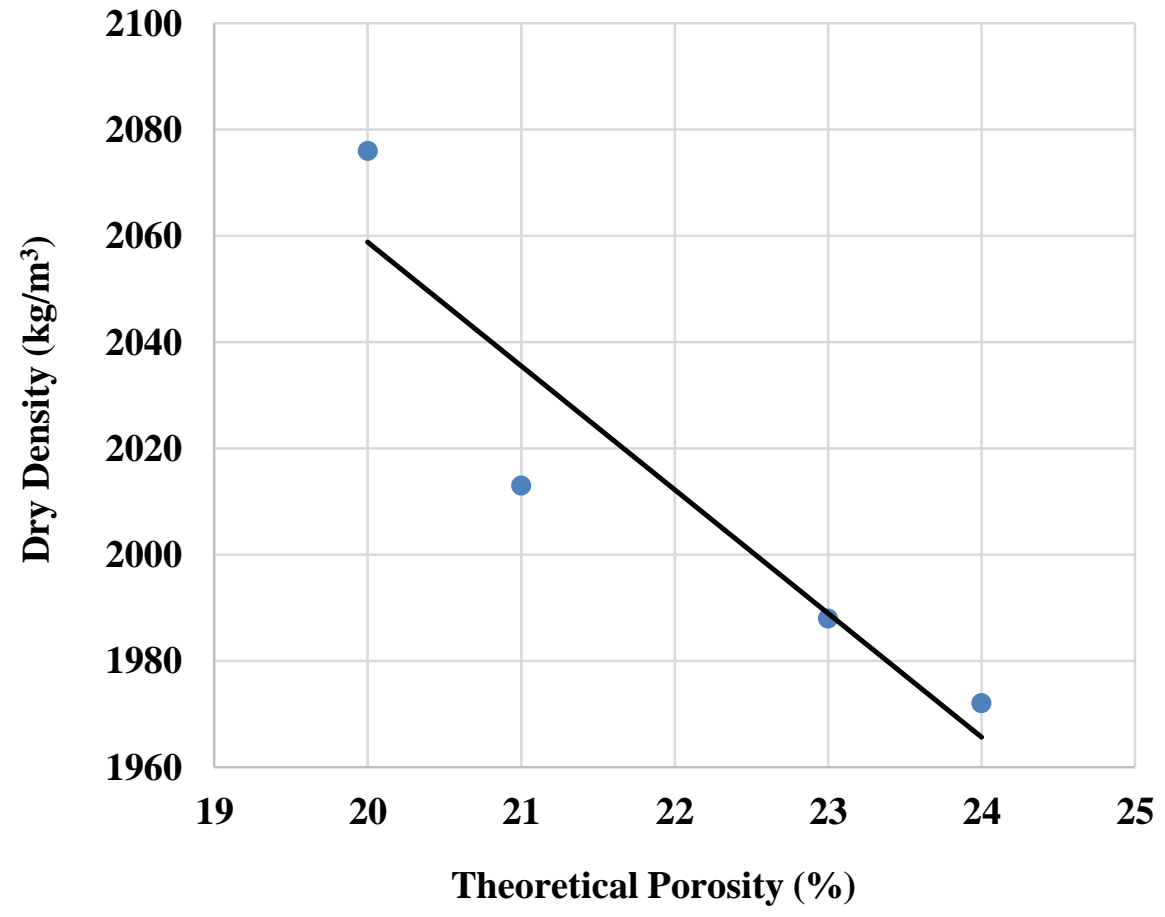

Fig. 9. Theoretical Porosity vs Dry Density for no fines pervious concrete 


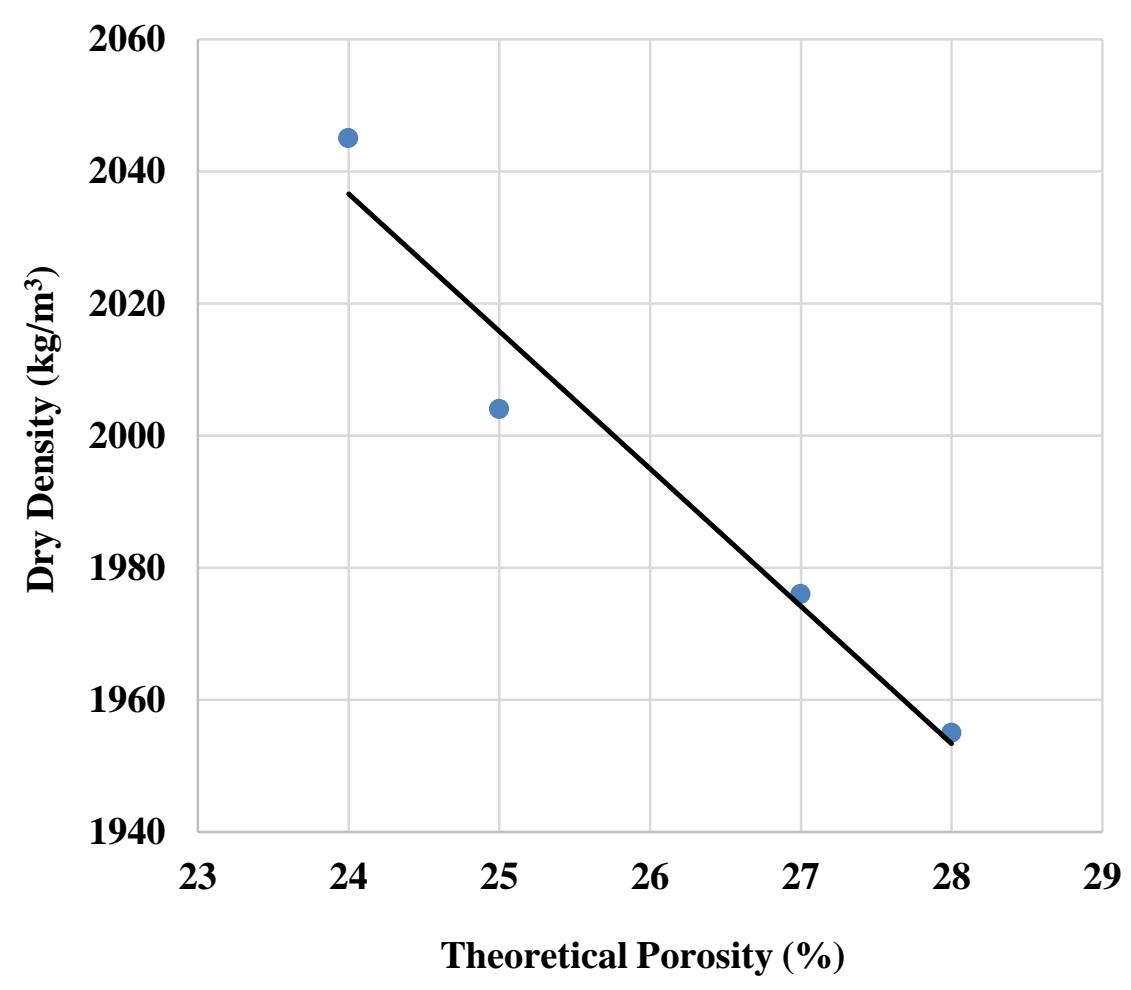

Fig. 10. Theoretical Porosity vs Dry Density for pervious concrete with $5 \%$ fines

- The range of the compressive strength achieved at 7-day and 28-day was between 7.38 $\mathrm{MPa}$ to $12.79 \mathrm{MPa}$ and $10.07 \mathrm{MPa}$ to $15.82 \mathrm{MPa}$ respectively. For best aggregate coating and paste stability, water-cement ratio was kept below 0.40 .

- The range of water permeability obtained at 7-day and 28-day was between 0.55 to 1.40 $\mathrm{cm} / \mathrm{sec}$ and 0.38 to $1.25 \mathrm{~cm} / \mathrm{sec}$ respectively for no fines concrete. The range of water permeability obtained for pervious concrete with $5 \%$ fines at 7-day and 28-day was between 0.31 to $1.11 \mathrm{~cm} / \mathrm{sec}$ and 0.23 to $1.02 \mathrm{~cm} / \mathrm{sec}$ respectively. The permeability decreased with the introduction of fine aggregate in the mixes. The variation of water permeability with theoretical porosity is shown in fig. 3 and 4.

- It can be seen that although the compressive strength of pervious concrete increased with the introduction of fine aggregate in the mixes, however, the strength is not increasing in direct proportion with the decrease in theoretical porosity. This is due to the reason that compressive strength, in addition to porosity, depends on water-cement ratio and pore size distribution in the concrete. Pore size refinement may have occurred due to introduction of fine aggregate.

- The range of dry density was between $1955 \mathrm{~kg} / \mathrm{m}^{3}$ to $2045 \mathrm{~kg} / \mathrm{m}^{3}$ for no fines concrete and between $1972 \mathrm{~kg} / \mathrm{m}^{3}$ to $2076 \mathrm{~kg} / \mathrm{m}^{3}$ for concrete with $5 \%$ fines. The dry density increased with the introduction of fines in the concrete.

\subsection{Plastic Concrete}

From set $\mathrm{A}$, given in table 5 below, it is clear that the various mix proportions like cement, coarse aggregate, fine aggregate and water are same for mix ID 1, 2 and 3. The only variable factor is the Bentonite content. Similarly, the same trend follows for the mix proportions given in set B and set $\mathrm{C}$. 
Table 5. Test Results

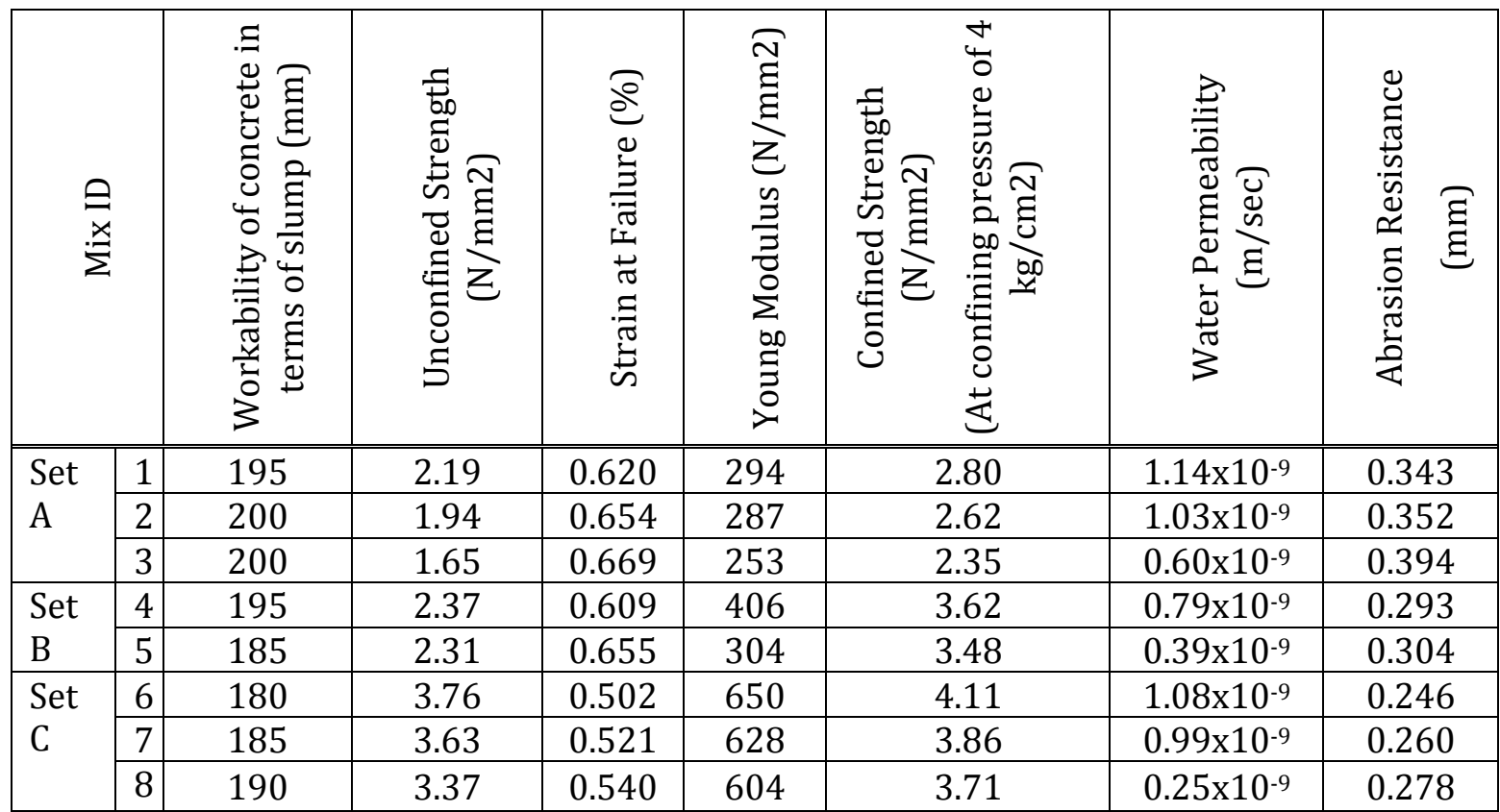

From the test results given in set $\mathrm{A}, \mathrm{B}$ and $\mathrm{C}$, it is clear that:

- Unconfined and confined compressive strength of plastic concrete decreased as Bentonite content was increased within the same set as shown in Fig 11 \& 12

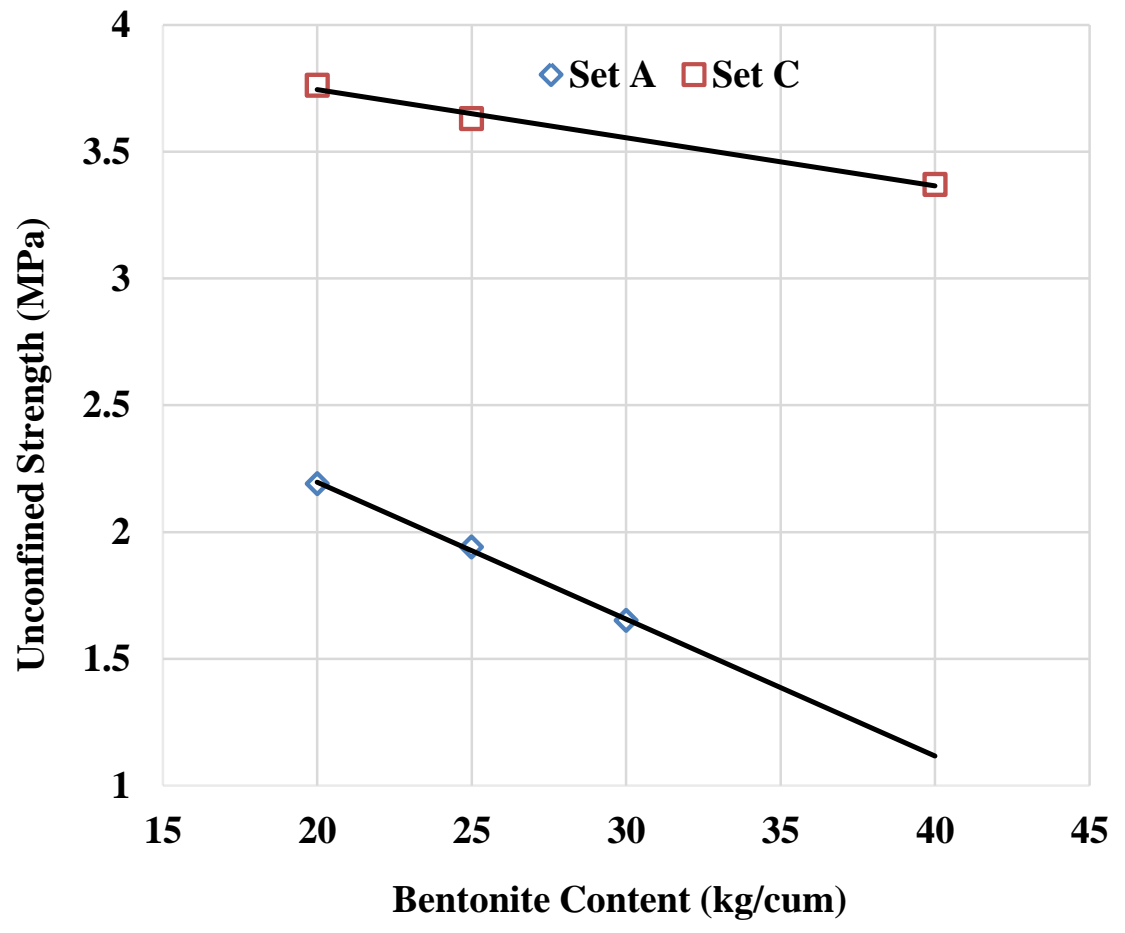

Fig. 11. Unconfined Strength vs Bentonite Content for results given in set A \& C 


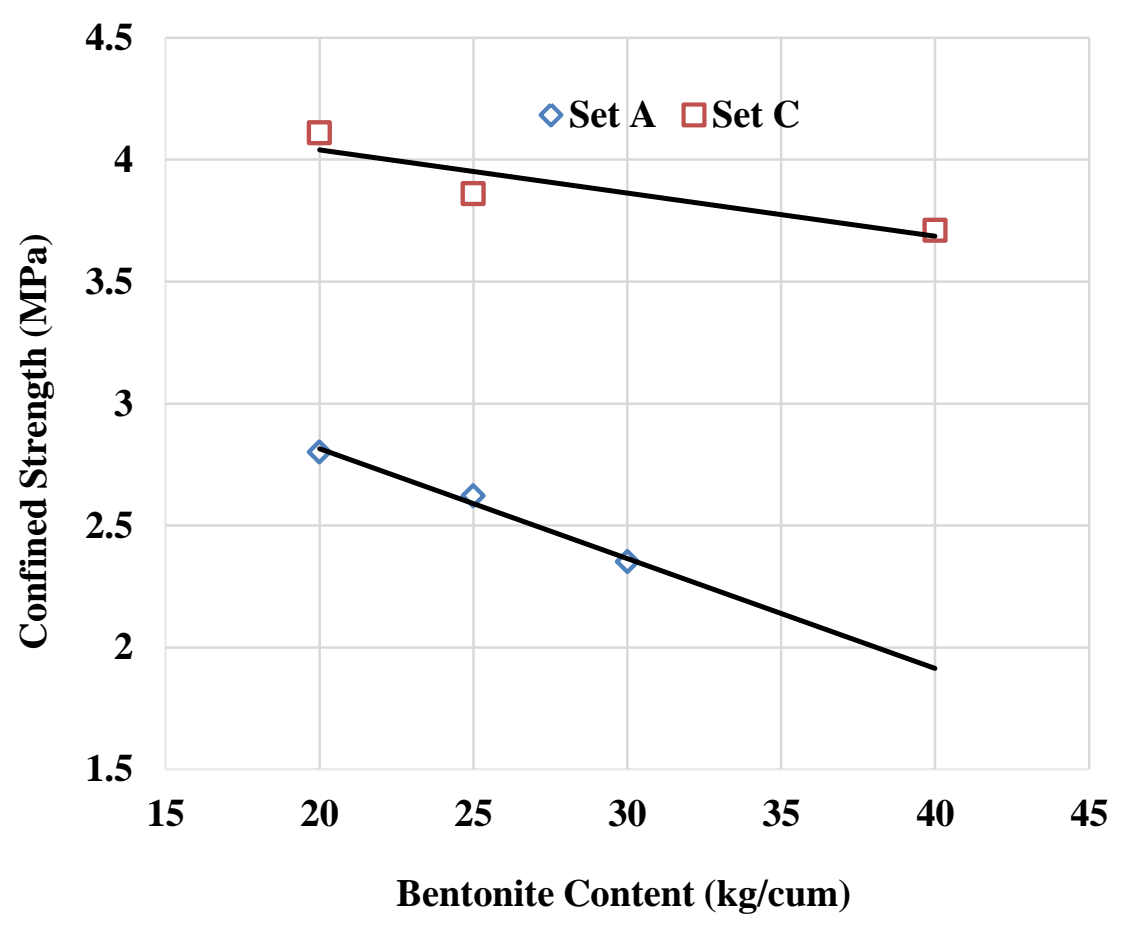

Fig. 12. Confined Strength vs Bentonite Content for results given in set A \& C

- Strain at failure increased with increase in Bentonite content in the same set due to increased deformations in plastic concrete as shown in Fig 13.

- Young Modulus of plastic concrete decreased with increase in Bentonite content within the same set as shown in Fig 14.

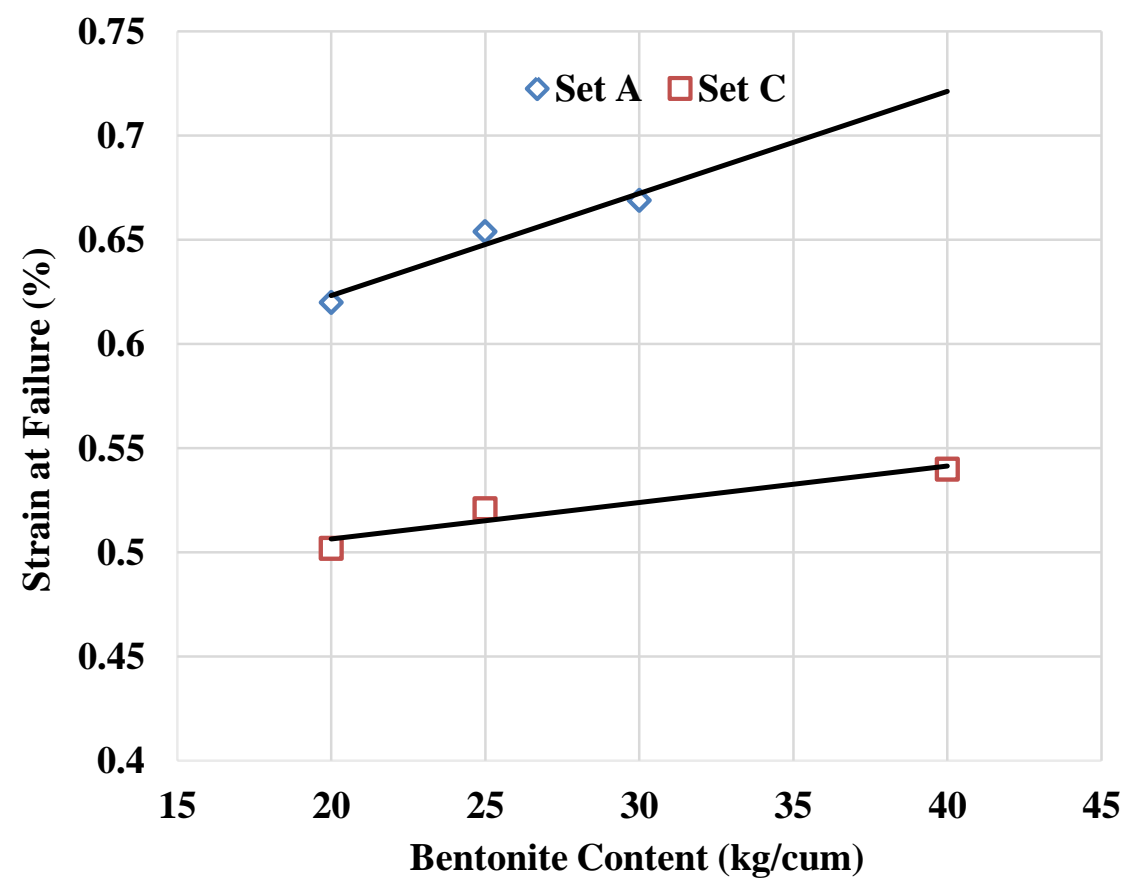

Fig. 13. Strain at failure vs Bentonite content for results given in set A \& C 


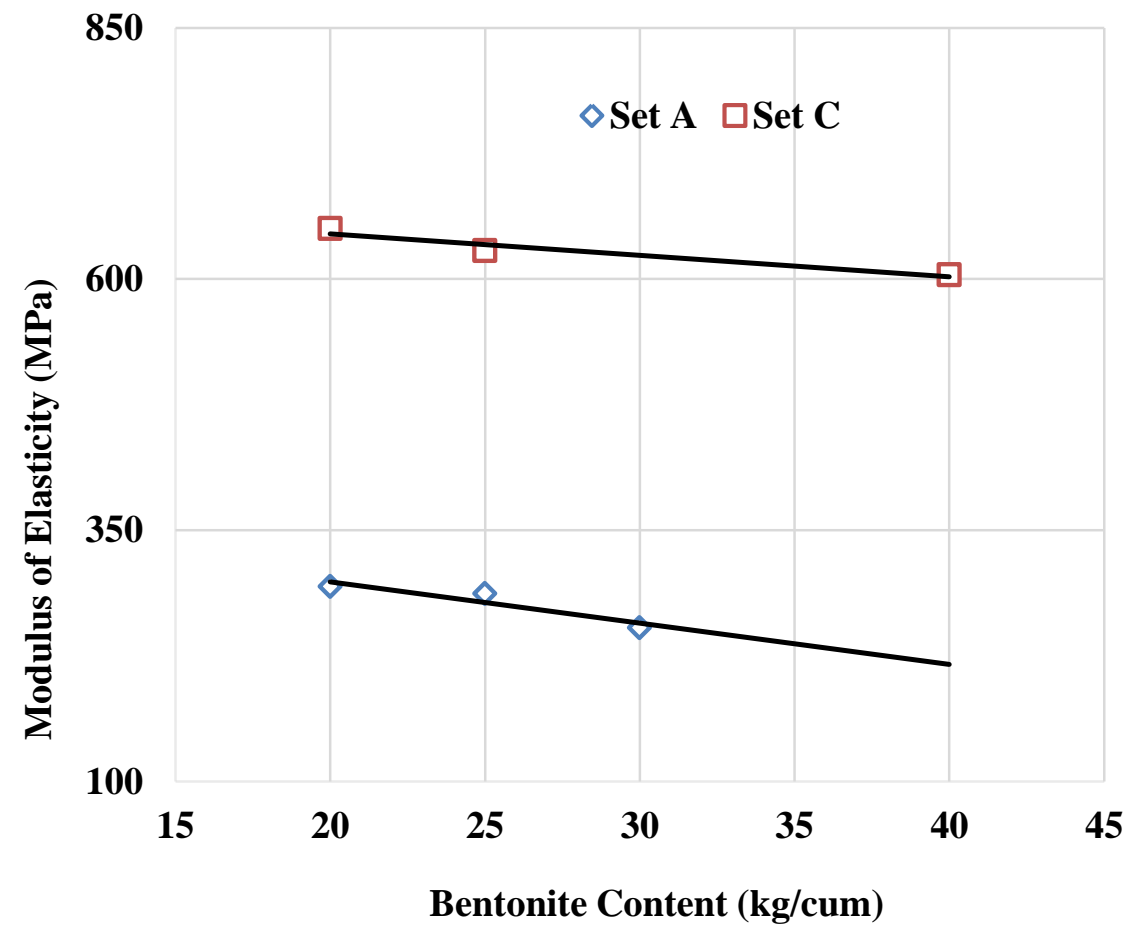

Fig. 14. Modulus of Elasticity vs Bentonite content for results given in set A \& C

- The water permeability of plastic concrete decreased with the increase in Bentonite content within the same set of trials as shown in Fig 15.

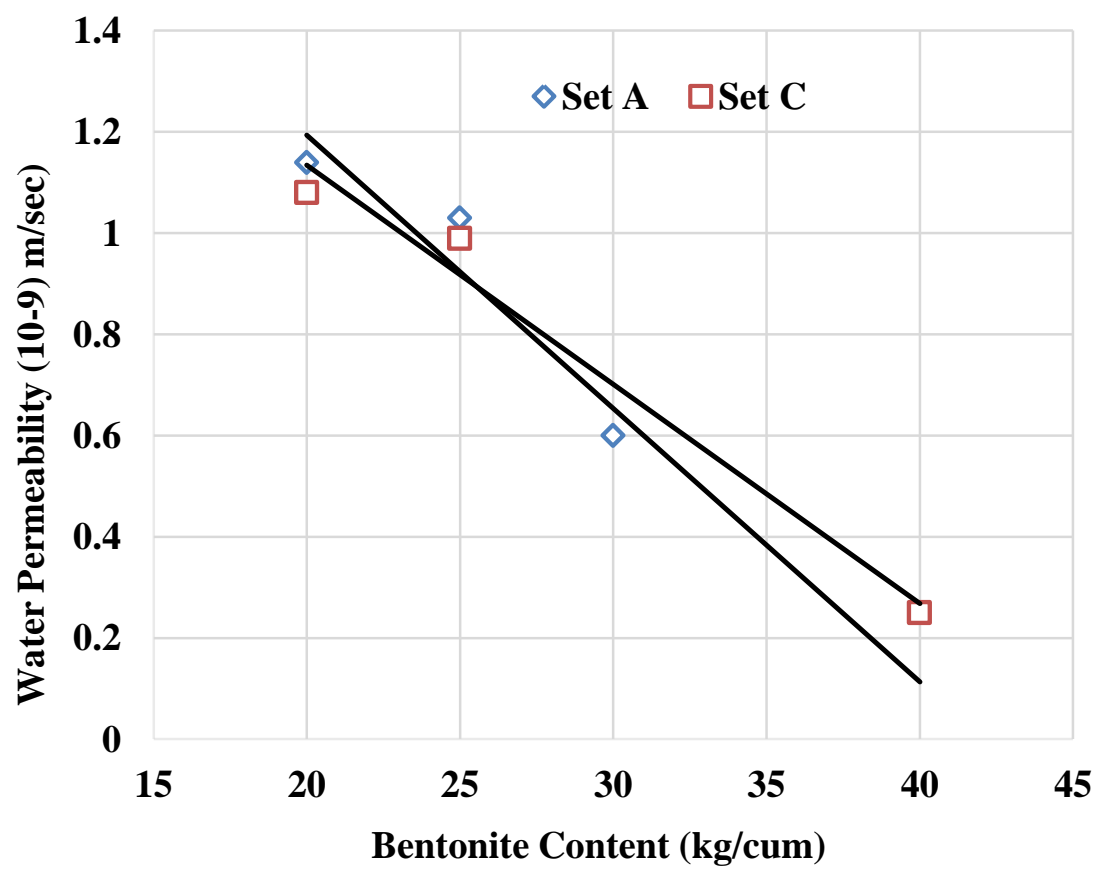

Fig. 15. Water permeability vs Bentonite content for results given in set A \& C

- The value of abrasion resistance decreased as the Bentonite content was increased within the same set of trials as shown in Fig 16. 
- On comparison of test results of set A, B and C, it is clear that with increased cement content and constant Bentonite quantity, unconfined and confined strength of plastic concrete increased, strain at failure decreased, Young Modulus increased, water permeability decreased and abrasion resistance increased.

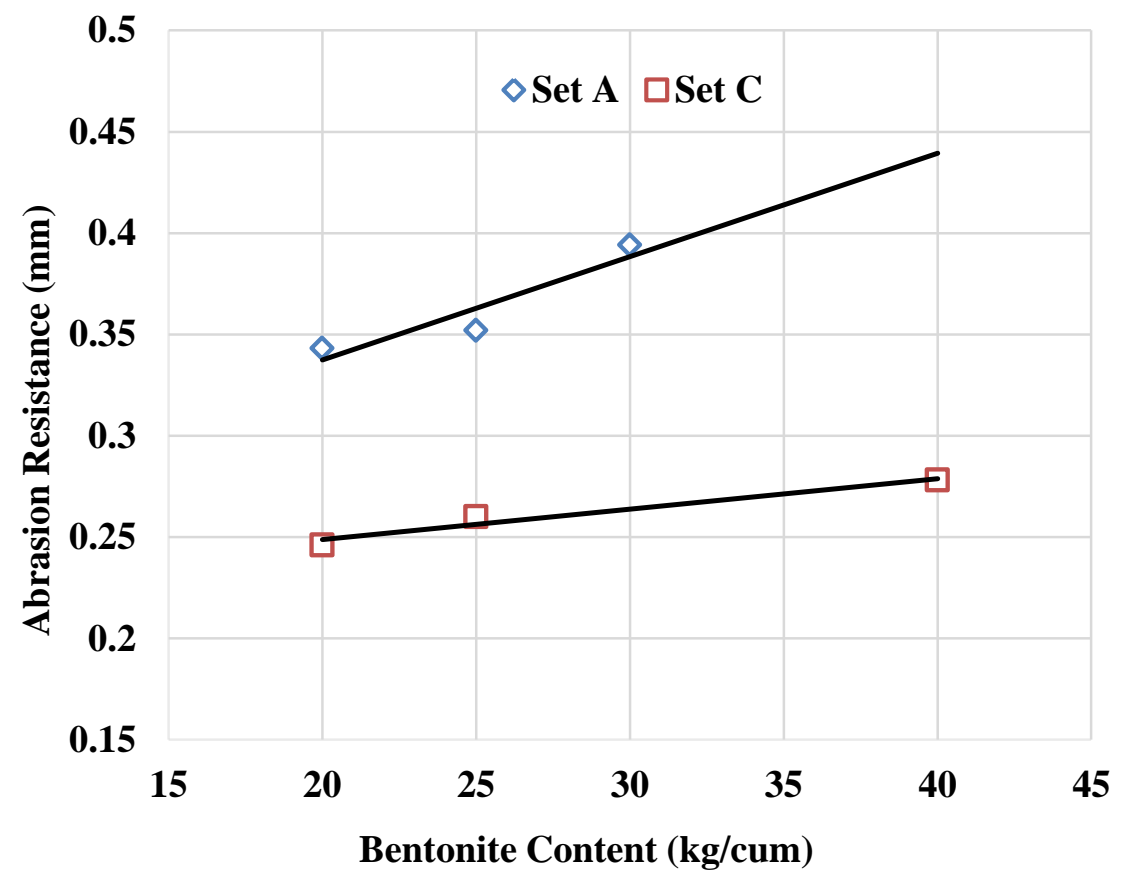

Fig. 16. Abrasion Resistance vs Bentonite content for results given in set A \& C

\subsection{Controlled Low Strength Material (CLSM)}

The various tests carried out on CLSM like bleeding, density, compressive strength and water permeability are discussed below and given in Table -6 .

Table 6. CLSM Test Results

\begin{tabular}{|l|l|l|l|l|}
\hline Sl. No. & $\begin{array}{l}\text { Workability of } \\
\text { concrete obtained in } \\
\text { terms of slump }(\mathrm{mm})\end{array}$ & $\begin{array}{l}\text { 7-Day comp. } \\
\text { strength of cube } \\
\left(\mathrm{N} / \mathrm{mm}^{2}\right)\end{array}$ & $\begin{array}{l}\text { 28-Day comp. } \\
\text { strength of cube } \\
\left(\mathrm{N} / \mathrm{mm}^{2}\right)\end{array}$ & $\begin{array}{l}\text { Density of } \\
\text { Hardened } \\
\text { CLSM }\left(\mathrm{Kg} / \mathrm{m}^{3}\right)\end{array}$ \\
\hline Mix-1 & 180 & 0.80 & 1.45 & 2122 \\
\hline Mix-2 & 170 & 1.20 & 2.99 & 2126 \\
\hline Mix-3 & 170 & 1.40 & 3.62 & 2132 \\
\hline Mix-4 & 165 & 0.85 & 1.77 & 1976 \\
\hline Mix-5 & 195 & 1.82 & 3.68 & 1954 \\
\hline Mix-6 & 185 & 1.65 & 3.09 & 1832 \\
\hline Mix-7 & 180 & 0.66 & 1.47 & 1736 \\
\hline
\end{tabular}

- There was no significant bleeding or segregation observed because only fine aggregates and fillers were used in all the mixtures instead of coarse aggregate. Fine particles have smaller void between the particles. With less voids, particles are less likely to be dislocated. Unless excessive free water exists or terrible bleeding occurs, segregation of 
CLSM designed with fine aggregates only is very unlikely to happen (Katz and Kovler, 2004).

- The density of CLSM in this experiment obtained varied from $1736 \mathrm{~kg} / \mathrm{m}^{3}$ to $2126 \mathrm{~kg} / \mathrm{m}^{3}$ which is consistent with the results found by Horiguchi et al. (2001), as per which the range of CLSM density varies from $1338 \mathrm{~kg} / \mathrm{m}^{3}$ to $2056 \mathrm{~kg} / \mathrm{m}^{3}$.

- It is clear that the higher quantity of cement used produced CLSM with higher compressive strength as it has lower water/cement ratio. More cement used can generate more strength as particles are more effectively bonded together (Neville, 1996).

- The coefficient of Permeability of CLSM was in the range of $1.00 \times 10-8 \mathrm{~cm} / \mathrm{sec}$ which is lower than clay that has relatively low permeability with a coefficient of Permeability in the range of $1.00 \times 10-7 \mathrm{~cm} / \mathrm{sec}$.

- The fly ash used in the study of CLSM conforms to IS: 3812 (Part 2) which is of inferior quality as compared to the fly ash conforming to IS: 3812 (Part 1). As the fly ash content used in the study is as high as $1200 \mathrm{~kg} / \mathrm{m} 3$, fly ash being a by-product produced by power plants, has a great potential to be used in CLSM as landfill and backfill material.

\section{Conclusions}

Based on the above study carried out on pervious concrete, plastic concrete and CLSM, following conclusion can be drawn:

\section{Pervious Concrete}

- There is a relationship between theoretical porosity/ actual porosity and water permeability. The graphs between theoretical/actual porosity and water permeability at zero \% of fine aggregate and with introduction of fine aggregate with increment of $5 \%$ can be generated to develop concrete mix design guidelines for pervious concrete.

- The introduction of fine aggregate produces more dense mix as compared to no fines mix, resulting in increased compressive strength.

- The compressive strength and water permeability of pervious concrete depends on water-cement ratio, porosity, pore size distribution and fine aggregate content. Hence, these parameters should be appropriately adjusted in order to obtain the required compressive strength and water permeability for design of pervious concrete.

\section{Plastic Concrete}

- Bentonite is the main constituent materials of plastic concrete which enhances its impermeability and ductility.

- The unconfined and confined compressive strength is significantly lower and water permeability is the same range of the conventional concrete because of the presence of Bentonite in the concrete.

- In case of plastic concrete, the strain is higher and Young Modulus is lower than the conventional concrete. These properties of plastic concrete make it more flexible and ductile and help in reducing the cracks that would otherwise be created due to differential settlements between concrete and the soil underneath.

- Mahmood (2005) has concluded that increasing the quantity of bentonite from $15 \mathrm{~kg} / \mathrm{m}^{3}$ to about $28 \mathrm{~kg} / \mathrm{m}^{3}$, the compressive strength \& modulus of elasticity increase, but when bentonite increases beyond about $30 \mathrm{~kg} / \mathrm{m}^{3}$, these parameters are decreased. However, 
in this study, the value of these parameters decreased throughout with the increase in bentonite content.

\section{Controlled Low Strength Material (CLSM)}

- For design of CLSM, the cement content can be kept in the range of $30 \mathrm{~kg} / \mathrm{m}^{3}$ to 70 $\mathrm{kg} / \mathrm{cm}^{3}$, siliceous fly ash content in the range of $460 \mathrm{~kg} / \mathrm{m}^{3}$ to $1200 \mathrm{~kg} / \mathrm{m}^{3}$ and fine aggregate quantity in the range of $120 \mathrm{~kg} / \mathrm{m}^{3}$ to $1360 \mathrm{~kg} / \mathrm{m}^{3}$ in order to produce a selfcompacting flowable, low strength and less permeable concrete.

CLSM has a great potential of utilization of even inferior quality of fly ash. This material can be used as landfill and backfill material as an alternative to the conventional granular materials utilizing this industrial waste material i.e. fly ash.

\section{References}

ACI, (1990). Cement and Concrete Terminology, ACI 116R-90, Manual of Concrete Practice, American Concrete Institute, Detroit, MI.

ACI, (1994). Controlled Low-Strength Materials (CLSM), American Concrete Institute, Committee ACI 229R-94 Report.

ACI, (2002), Guide for Selecting Proportions for No-Slump Concrete Reported by ACI Committee 211.3R02. In American Concrete Institute.

ACI, (2006). Pervious Concrete. Committee 522R-06, American Concrete Institute, Farmington Hills, Michigan.

Horiguchi, T., Okumura, H., \& Saeki, N. (2001). Optimization of CLSM mix proportion with combination of clinker ash and fly ash. Special Publication, 199, 307-324.

Kajio, S., Tanaka, S., Tomita, R., Noda, E., \& Hashimoto, S. (1998). Properties of porous concrete with high strength. In Proceedings 8th international symposium on concrete roads, pp. 171-177.

Katz, A., \& Kovler, K. (2004). Utilization of industrial by-products for the production of controlled low strength materials (CLSM). Waste Management, 24(5), 501-512.

Naderi, M. (2005). Effects of different constituent materials on the properties of plastic concrete. International Journal of Civil Engineering, 3(1), 10-19.

Neville, A.M. (1996). Properties of Concrete, $4^{\text {th }}$ Edition ed. Edinburgh Gate, Horlow, Longman.

Tennis, P. D., Leming, M. L., \& Akers, D. J. (2004). Pervious concrete pavements, Special Publication by the Portland Cement Association and the National ready Mixed Concrete Association Skokie, IL.

Wang, K., Schaefer, V. R., Kevern, J. T., \& Suleiman, M. T. (2006). Development of mix proportion for functional and durable pervious concrete. In NRMCA concrete technology forum: focus on pervious concrete, Nashville, pp. 1-12.

Youngs, A. (2005). Pervious concrete it's for real. In Presentation at pervious concrete and parking area design workshop, Omaha. 